\title{
Entrepreneurship analysis in Spanish universities
}

\author{
Gemma Renart Vicens, Laura Vall-llosera Casanovas, \\ Carme Saurina Canals and Laura Serra \\ Economics, University of Girona, Girona, Spain
}

\begin{abstract}
Purpose - Entrepreneurship requires the attitudes and capabilities needed to begin new and innovative projects able to create positive impacts in the economy of a society. Given that it forms the basis from which new companies, products and innovations emerge, it is a very relevant term in business. With the aim of strengthening these capabilities, many universities are incorporating new educational strategies into their curricula to boost entrepreneurial intention and business skills among their students. This study aims to determine the factors that intervene in the entrepreneurial spirit of students in Spanish universities by examining areas of study, different personal and contextual characteristics, and the type of training students receive in entrepreneurship.

Design/methodology/approach - Data collected from 33,182 students in 77 Spanish universities in the 2018 edition of the Global University Entrepreneurial Spirit Students' Survey (GUESSS) is examined in an exhaustive univariate and bivariate descriptive and inferential analysis. Furthermore, the relationship between the entrepreneurial index and the different explicative variables is modelled, and a basic random effect for the area of study is introduced to detect differences at this level.

Findings - Economics, engineering and health sciences presented higher than average entrepreneurial indices. Regarding the type of training, only voluntary education in entrepreneurship influenced entrepreneurial spirit, albeit not equally in all areas of study.

Originality/value - This study's results can help universities to incorporate new educational strategies into their curricula to boost entrepreneurial intention and business skills among students by focusing resources where they are most efficient.
\end{abstract}

Keywords Entrepreneurial spirit, Higher education, Multilevel models, Entrepreneurship education, University entrepreneurship

Paper type Research paper

\section{Introduction}

Entrepreneurship is an important factor for the development and growth of economies. Entrepreneurs and their innovations make a large contribution to increasing the wealth of countries, creating jobs and adding to their populations' well-being. To this effect, identifying the entrepreneur's profile and determining the factors associated with entrepreneurial intention are subjects that have generated much interest and have been addressed in economics, sociology, management and psychology, among other subjects (Küttim et al., 2014).

Several of these approaches agree that entrepreneurship education improves the development of the traits associated with entrepreneurial success, proving that entrepreneurship can be taught or at least incentivised (Valencia et al., 2015). As such, many universities have incorporated new educational strategies and teaching methodologies

(C) Gemma Renart Vicens, Laura Vall-llosera Casanovas, Carme Saurina Canals and Laura Serra. Published by Emerald Publishing Limited. This article is published under the Creative Commons Attribution (CCBY 4.0) licence. Anyone may reproduce, distribute, translate and create derivative works of this article (for both commercial and non-commercial purposes), subject to full attribution to the original publication and authors. The full terms of this licence may be seen at http://creativecommons. org/licences/by/4.0/legalcode

Funding: This work has been supported by Càtedra de Joves Emprenedors at University of Girona.
Spanish
universities

eceived 10 November 2020

Revised 9 January 2021 23 April 2021

17 May 2021

Accepted 24 May 2021

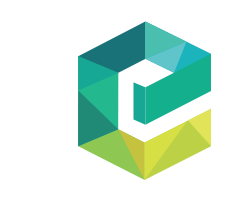

Higher Education, Skills and Work-Based Learning Emerald Publishing Limited 2042-3896 
into their curricula in an aim to increase their students' propensity towards considering creating a company as a career path. While it has been shown that education has an impact on entrepreneurial intention, there is heated debate as to whether it mediates equally among all students or if it is more effective in individuals with certain prior traits. So, although entrepreneurship education in universities has promoted the creation of student start-ups, the effect appears to differ significantly depending on the demographic, academic and/or social profile of the students themselves. Determining what combination of traits makes individuals more receptive to entrepreneurial intention will not only help universities to provide effective support for those students who will benefit most from this specific education but also to identify the best strategies for the rest.

\section{Background}

Over time, entrepreneurship analysis has focused on four main areas: (1) entrepreneurs' personal factors; (2) entrepreneurs' psychological characteristics; (3) contextual and institutional factors that facilitate entrepreneurial trends and (4) the importance of entrepreneurship in disruptive innovation and its contribution to the economic growth and job creation.

The dominance of quantitative methods means that the study of entrepreneurship has focused on questions that can be answered with quantitative data. As a result, more has been studied about who, what, when and how much, than about how or why (McDonald et al., 2015). From this preeminence of quantitative studies, some problems need to be taken into account.

First, and as it is well known, quantitative methods focus primarily on surveys or interviews to generate knowledge about the decision-making process. The use of these tools involves collecting post-hoc data that require respondents to recall and evaluate previous decisions. This memory and evaluation task can generate bias that could reduce the quality of the data obtained.

Data quality is the second aspect to consider. While is it true that there are high-quality public databases, these data are mostly cross-sectional, unrelated and not always easily accessible to researchers. Furthermore, cross-sectional data allows variables to be analysed from a static perspective, but they do not cover the dynamic process of relationships, for example, between the evolution of entrepreneurship and regional growth. Recently, some efforts have been made to obtain and analyse longitudinal data in entrepreneurial studies (Reynolds, 2017). Some examples, such as the Panel Study on Entrepreneurial Business (PSED) or the Kauffman Firm Survey (KFS), show that is it possible to obtain information and track entrepreneurs.

The final problem refers to different aspects of the sample. Entrepreneurs are a difficult population to identify, thus making sampling difficult. In addition, the relationship between successful and intentional entrepreneurs is low. This means that many people who should be part of entrepreneurial studies, because they have the entrepreneurial characteristics, are excluded because they have not been successful in business. These two problems can lead us to unrepresentative samples and, therefore, to unreliable results.

Despite the problems associated with quantitative approaches, we should also be critical of qualitative methods. Understanding the actors' point of view from the perspective of their ecosystem and analysing the way they perceive and live their realities is not free from methodological problems (Quezada et al., 2020).

To begin with, in the qualitative studies, the sample configuration is determined by the identification and selection of a relevant context for the research problem. This implies taking into account the difficult balance between accessibility and the degree of heterogeneityhomogeneity of the sample.

On the other hand, the theoretical proposals that are generated in qualitative studies acquire value because of their holistic nature, for the reason that they arise from a population 
with specific characteristics and from a concrete socioeconomic and demographic context. This feature may be a limitation because it does not allow for the results to be generalised to other similar groups in different contexts.

Last but not least, many of these studies do not allow for casual statistical inference.

The limitations of both approaches seem to indicate that a plurality of methodologies might be the best way to obtain a complete view of this complex phenomenon. Obviously, the ultimate study goal - establishing causal relationships, making inferences, delving into a particular aspect, etc. will help us to determine which methodological approach should have more weight in our work.

Whatever methodological approach is chosen, is widely recognised that entrepreneurship involves starting new businesses, experimenting with new technologies, introducing new products and creating new markets. So entrepreneurs are agents of regional change (García et al., 2012; Liñán et al., 2013).

Entrepreneurial intention can be defined as a mindset focused on reaching an objective in this case creating a company or a business - thus influencing the actions of said entrepreneur to achieve this objective (Prodan and Drnovsek, 2010). One of the types of models most used to measure intention is based on the theory of planned behaviour (TPB), which sustains that intention depends on the attitude, subjective norm and control over the behaviour of the individual (Ajzen, 1991). Thus, once an individual's degree of intention has been determined, this can then be related to their personal and contextual characteristics in order to establish what the determinant factors of this intention are (Küttim et al., 2014).

To this effect, the current literature makes several clear contributions on how gender, age, family background and employment experience influence entrepreneurial intention. For instance, many studies have associated being male with creating companies. While some research appears to indicate women's increasing participation in the initial stages of creating a company (Guerrero and Serey, 2018), the sociocultural values of the environment in which these women develop appear to be potentially serious obstacles to starting, managing and directing new business projects (Merino and Vargas Chanes, 2011; Salazar et al., 2014).

Along with gender, age as a variable of influence regarding company creation has also been an object of broad study in recent years. In general, previous works have considered that with age, certain aptitudes to detect opportunities decline and propensity to risk increases (Salcedo et al., 2018). Hence, young people with no family or other commitments are those who, mostly, tend to create their own companies.

Family tradition is another factor that has been shown to be extremely important in creating an environment for developing new business ideas. Observation has confirmed that a large proportion of the individuals that show high entrepreneurial intention come from families in which there is already a business or self-employed person, usually one of the two parents (Jaen et al., 2013; Liñán et al., 2010).

Likewise, numerous studies have shown that professional experience, like family tradition, is a positive factor in creating and successfully developing entrepreneurial projects. The theory of the company as an incubator explains that the defining skill of the entrepreneur is acquired through a combination of personal and work experience, which then later helps the individual to take decisions that are favourable for entrepreneurship (Levia et al., 2014).

While it appears to be clear that entrepreneurial intention is more likely in individuals with certain demographic and socioeconomic characteristics, there is currently debate in the literature as to whether entrepreneurial education and training sway an individual's feeling of being capable of and motivated to be an entrepreneur. The last Global Entrepreneurial Monitor (GEM) report (González-Pernía et al., 2019) determines that many entrepreneurs are university educated, indicating that this is an objective population among which entrepreneurship can be promoted or, where necessary, increased. As such, it is important to 
establish when this type of teaching should begin, and how it should be included in university curricula.

At the international level, both in Europe and the Americas, entrepreneurship education within the university education system is mainly focused on teaching methodologies associated with business models such as Canvas, leaving aside the fundamental aspects associated with the entrepreneur's motivations, capabilities and skills. Other strategies, from participating in ideas competitions and learning how to create business plans to develop projects to learning about successful entrepreneurs' experiences and studying specific cases, are incorporated later to give entrepreneurial ideas real value and to create business plans that aim to provide specific solutions to real problems in the country or region in question.

Most Spanish universities have guidelines and strategies for educating entrepreneurs that are applied in different degree courses, although not always transversally. The most usual methodology is one characterised by generating support programmes, treating the students as if they were entrepreneurs and giving them access to tools and resources to launch their businesses. However, as in other countries, strategies to incentivise entrepreneurial intention are not featured.

Given this apparent gap, the most frequently asked question in this scenario is whether these university-level interventions are effective. So-called entrepreneurship education argues that entrepreneurship can be taught (or at least incentivised) through education programmes that enable the traits associated with entrepreneurial success to be developed and that teach the skills that the entrepreneurs will later need. Formal entrepreneurial education would therefore impact on students' attitudes and influence the future direction of their entrepreneurial career when they leave university. To this effect, Ahn and Park (2017) prove a positive direct effect of entrepreneurship education on encouraging the entrepreneurship and self-efficacy of university students. Saji and Nair (2018) also determine that program efficacy in entrepreneurship courses has a positive effect on students' self-perceptions about entrepreneurship values and attitudes. Furthermore, Mourao and Schneider (2020) observe that university students' entrepreneurial skills can be developed through training.

There are other works, however, that find that university is not fulfilling its function as an incubator of business ideas and entrepreneurial attitudes among its students (Hassan, 2020). As Fayolle and Gailly (2013) point out, the positive effects of entrepreneurship education programs (EEPs) are more evident when previous entrepreneurial exposure has been weak or inexistent. Conversely, for those students who had been significantly exposed to entrepreneurship previously, the results highlight significant countereffects of the EEP. Likewise, in their study related to testing if selected psychological traits mediated the predictive relationship between the perceived effects of entrepreneurship education and entrepreneurial intentions, Ndofirepi (2020) finds that educational programmes succeed only if individuals with acquiescent entrepreneurial traits take part.

This disparity in opinions as to the effect entrepreneurship education has on the entrepreneurial intention of university students arises from the fact that the studies carried out until now are not based on the same study population nor do they consider the same factors related to entrepreneurship education. Hence, disparate results concerning how education intervenes in entrepreneurial intention can be obtained depending on whether the entire university population or just one specific degree is analysed, or whether the entrepreneurial education offered is mandatory, or optional is considered.

Therefore, starting from these divergences of results in the previous literature, this study aims to determine the intervening factors in the entrepreneurial spirit of Spanish university students, depending on their area of study and the type of (voluntary or mandatory) entrepreneurship education received. 
By addressing this subject from a novel perspective, comparing the different areas of study among the same sample and taking into account the type of entrepreneurial education received, this paper contributes to shedding light on the effect that entrepreneurship education has on university students and tests the degree of effectiveness of these policies.

\section{Methodology}

The data collected in the 2018 edition of the international Global University Entrepreneurial Spirit Student's Survey (GUESSS) for a total sample of 33,182 students from 77 Spanish universities (Sieger et al., 2011) were analysed.

The survey is structured into 11 sections, each referring to one of the different items related to the entrepreneurial character. In the present work, the answers given by the students corresponding to the first seven sections were analysed because these had the highest rate of answers.

First, the descriptives of the main characteristics of the students in the sample were calculated, including their stated intentions with respect to their employment situation in the immediate future. Using the principal component analysis (PCA) for the different groups of questions, measured on a seven-point Likert scale, four new numerical variables (or indices) were constructed with the aim of reducing the information contained in each group of questions into one single index, thus simplifying the handling of the conceptual information contained within them. The four indices created are a summary of the groups of questions about (1) entrepreneurial intentions and attitudes; (2) skills level and self-efficacy; (3) level of reaction in the student's surroundings and (4) support received from the university (Table 1).

The goodness of fit of when applying the PCA was analysed calculating the KaiserMeyer-Olkin (KMO) test. The percentage of variability explained and the value of the Cronbach's alpha coefficient indicates that the fit accurately summarised the most relevant information contained in each group of original variables.

Since belonging to a certain area of study can have an effect on entrepreneurial spirit, a multilevel regression model was examined. The index that measures intentions and attitudes regarding entrepreneurial character (spirit) was the dependent variable, which relies on different explicative variables of a demographic, social, educational and perceptive nature and on the rest of the indices created.

\begin{tabular}{|c|c|c|c|}
\hline $\begin{array}{l}\text { Name of the } \\
\text { variable }\end{array}$ & Description & $\begin{array}{l}\text { Questions } \\
\text { included }\end{array}$ & Reliability \\
\hline (1) Spirit & $\begin{array}{l}\text { Intentions and attitudes regarding the } \\
\text { entrepreneurial character }\end{array}$ & 11 questions & $\begin{array}{l}\text { KMO }=0.953 \\
S^{2} \text { explained: } 73.02 \% \\
\alpha \text { Cronbach: } 0.963\end{array}$ \\
\hline (2) Self-efficacy & Level of skill in carrying out entrepreneurial tasks & 7 questions & $\begin{array}{l}\text { KMO = } 0.911 \\
S^{2} \text { explained: } 68.40 \% \\
\alpha \text { Cronbach: } 0.923\end{array}$ \\
\hline (3) Environment & $\begin{array}{l}\text { Family, friends' and peers' reactions to their wanting to } \\
\text { start a career as an entrepreneur }\end{array}$ & 3 questions & $\begin{array}{l}\text { KMO = } 0.673 \\
S^{2} \text { explained: } 72.33 \% \\
\alpha \text { Cronbach: } 0.802\end{array}$ \\
\hline (4) University & $\begin{array}{l}\text { Support received from the university and from the } \\
\text { courses offered to facilitate and promote } \\
\text { entrepreneurship }\end{array}$ & 8 questions & $\begin{array}{l}\mathrm{KMO}=0.902 \\
S^{2} \text { explained: } 69.22 \% \\
\alpha \text { Cronbach: } 0.936\end{array}$ \\
\hline
\end{tabular}

Source(s): Compiled by the authors

Table 1. Creation of PCA variables 
These multilevel models assume a hierarchical structure in terms of the data, with the individuals grouped in higher level units, which can also be grouped into other units. In this case, a two-level structure was considered, where the students (level 1) were grouped by study areas (level 2). A random effect at the level of the intercept was also introduced to control for the effect of the area of study on the entrepreneurial behaviour of the students ( $\phi$-value of the Hausman test: 0.9823$)$. The specification of this model is as follows:

$$
y_{i j}=\beta_{0 j}+\sum_{p} \beta_{p} x_{p i j}+\varepsilon_{i j}
$$

where the subscript $i$ indicates the individual, the subscript $j$ the area of study and the subscript $p$ the covariate.

Finally, to understand the functional relationship between the independent variables and the entrepreneurial spirit for each specific area of study, a multiple linear regression model was estimated using the same explicative variables as in the global multilevel model, but separately for each sample of students from the different areas of study. In particular, this allows the effect voluntary or mandatory education has on entrepreneurial spirit depending on the area of study to be analysed.

$$
y_{i}=\beta_{0}+\sum_{p} \beta_{p} x_{p i}+\varepsilon_{i}
$$

\section{Results and discussion}

The sample was composed of a higher percentage of female students $(58.7 \%)$ and undergraduates $(82.7 \%$ ) (Table 2 ). The average age was 23.1 years with a standard deviation of 5.7 years given that it included postgraduate and doctoral students. A large percentage of the students $(24.7 \%)$ combined work and study. Few students, however, indicated that they were planning to start their own business $(15.2 \%)$, already had their own business or were self-employed (4.8\%). Almost 30\% of those surveyed had previously taken a voluntary course related to entrepreneurship.

When the area of study is projected onto the axes (defined by the four indices constructed using the PCA), different behaviour patterns emerge (Figure 1). The diagrams indicate that students from economics and engineering always have an above-average entrepreneurial spirit index. This coincides with a higher skill and entrepreneurial efficacy index along with consistently rating their personal and social support and the support received from the university more highly. At the opposite extreme, low values can be observed in all four indexes created in arts, sciences, health sciences, education and psychology.

The multilevel regression model (Table 3 ) shows that entrepreneurial spirit is related to being male and an undergraduate, but not to age. Also positively influencing the entrepreneurial spirit includes currently an entrepreneur, wanting to be an entrepreneur within the next five years, the father or both parents having their own business and/or combining working and studying. Having voluntarily taken courses specifically about entrepreneurship, having a positive perception of the support received from their personal and university environments, and self-efficacy, further influence entrepreneurial spirit positively.

Table 4 shows the random effects of the multilevel regression model. As can be seen, economics, engineering and health sciences present an above-average entrepreneurial spirit index, with economics having the highest index. At the opposite extreme are the rest of the areas with a lower-than-average index in all cases. That said, arts show the lowest levels of entrepreneurial spirit.

As previously mentioned, the estimated multilevel regression model shows how taking courses specifically about entrepreneurship only influences entrepreneurial spirit when they 


\begin{tabular}{|c|c|c|c|}
\hline Sex & $\begin{array}{l}\text { Man } \\
\text { Women }\end{array}$ & $41.3 \%$ & $\begin{array}{l}\text { spanish } \\
\text { universities }\end{array}$ \\
\hline \multirow[t]{2}{*}{ Level of study } & Graduate & $82.7 \%$ & \\
\hline & Master's degree, doctorate & $17.4 \%$ & \\
\hline \multirow[t]{8}{*}{ Area of study } & Arts & $9.1 \%$ & \\
\hline & Economics & $20.5 \%$ & \\
\hline & Engineering & $22.5 \%$ & \\
\hline & Health sciences & $13.3 \%$ & \\
\hline & Law & $6.1 \%$ & \\
\hline & Sciences & $8.2 \%$ & \\
\hline & Education psychology & $16.4 \%$ & \\
\hline & Other & $3.3 \%$ & \\
\hline \multirow[t]{2}{*}{ Type of student } & Full-time & $75.3 \%$ & \\
\hline & Works and studies & $24.7 \%$ & \\
\hline \multirow[t]{2}{*}{ Is currently an entrepreneur } & Yes & $4.5 \%$ & \\
\hline & No & $95.5 \%$ & \\
\hline \multirow[t]{2}{*}{ Wants to be an entrepreneur within five years } & Yes & $24.5 \%$ & \\
\hline & No & $75.5 \%$ & \\
\hline \multirow[t]{2}{*}{ Works in a company created in the last five years } & Yes & $19.7 \%$ & \\
\hline & No & $80.3 \%$ & \\
\hline \multirow[t]{2}{*}{ Plans to open their own business } & Yes & $15.2 \%$ & \\
\hline & No & $84.8 \%$ & \\
\hline \multirow[t]{2}{*}{ Has their own business or are self-employed } & Yes & $4.8 \%$ & \\
\hline & No & $95.2 \%$ & \\
\hline \multirow[t]{3}{*}{ Have taken a course specifically about entrepreneurship } & No & $62.9 \%$ & \\
\hline & Mandatory courses & $7.5 \%$ & \\
\hline & Voluntary courses & $29.5 \%$ & \\
\hline \multirow{2}{*}{ Age } & Average (standard deviation) & $23.1(5.7)$ & \\
\hline & Minimum/Maximum & $16 / 58$ & Descriptives of \\
\hline Source(s): Compiled by the authors & & & the sample \\
\hline
\end{tabular}

are voluntarily undertaken and that, in this case, the effect is positive. To investigate this relationship further, multiple linear regression models of entrepreneurial spirit with respect to the same explicative variables, but separately for the samples of each area of study [1], were estimated.

The significant results for each of the study areas were very similar to those already presented for the global model. It can be observed that taking courses specifically about entrepreneurship has no affect in any of the study areas when these courses are mandatory. This result changes, however, when the courses are attended voluntarily. In this case, entrepreneurial spirit is positive in all the areas of study except for economics and law (Figure 2).

\section{Conclusions}

Studies analysing the profile of the entrepreneur have customarily focused on determining why companies are created by people with certain traits. While intuitive aspects may have some influence, the action of creating a company is a rational decision and not the product of impulse or emotion. Consequently, there are many sociological studies (Bell et al., 2015; Díaz-García et al., 2015) that have found that intention is the best predictor of planned behaviour, especially with non-frequent behaviour, and that there are non-predictable delays between the decision and the action. As such, this has led to this TPB-based study into the motivations to become an entrepreneur.

The GUESSS, based on TPB, analyses entrepreneurial spirit among university students at the European level. It also collects the students' social, demographic and educational 


\section{HESWBL}

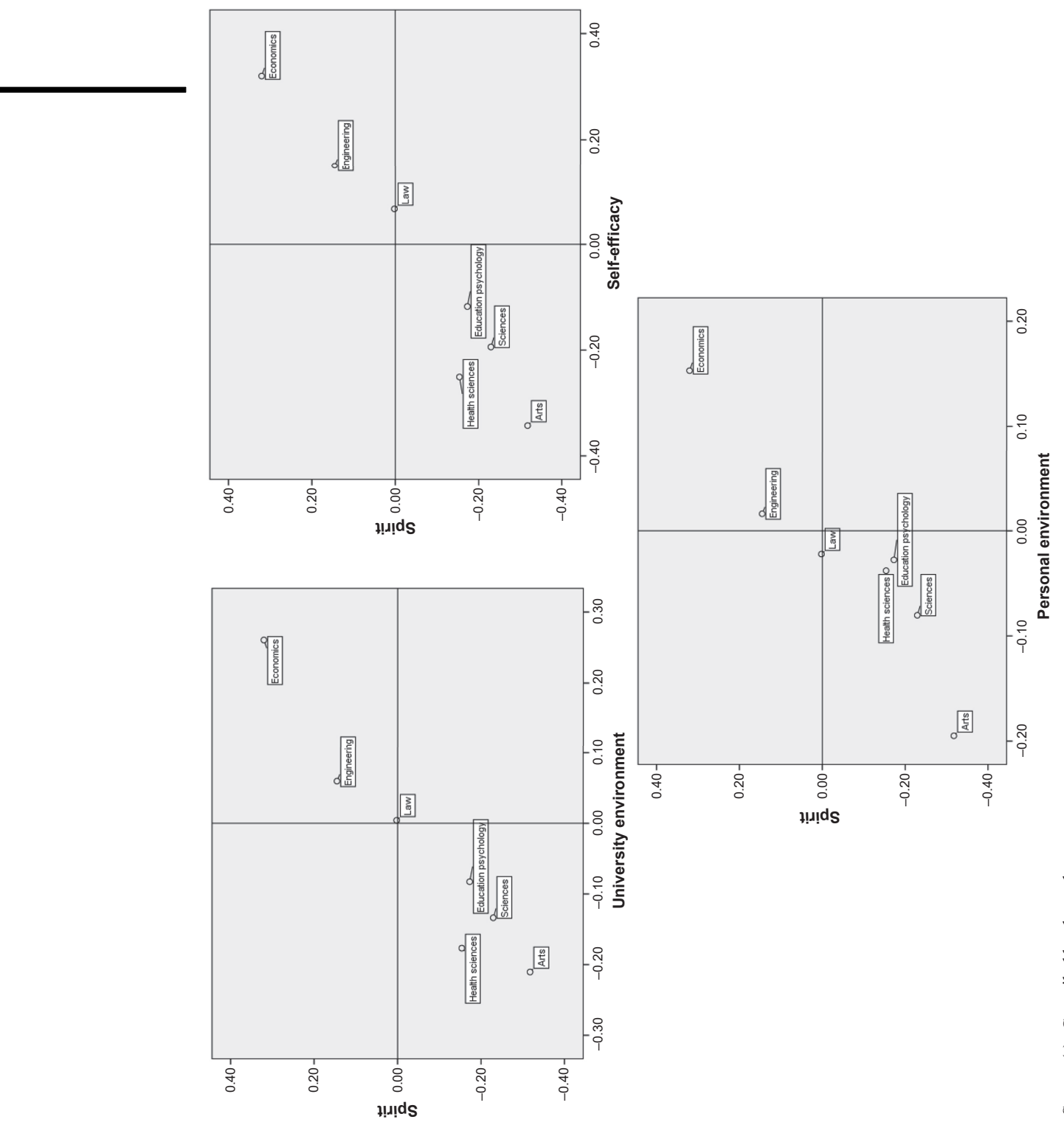

Figure 1.

Projection of the areas of study onto the axes defined in the PCA 


\begin{tabular}{|c|c|c|}
\hline Variable & Value (SD) & spanish \\
\hline $\begin{array}{l}\text { Sex (Man) } \\
\text { Woman } \\
\text { Age } \\
\text { Self-efficacy } \\
\text { University environment } \\
\text { Personal environment }\end{array}$ & $\begin{array}{l}-0.0546(0.0096) * * * \\
0.0008(0.0010) \\
0.4114(0.0053) * * * \\
0.0457(0.0051) * * * \\
0.1579(0.0048) * * *\end{array}$ & \\
\hline $\begin{array}{l}\text { Educational level (degree) } \\
\text { Master's }\end{array}$ & $-0.0767(0.0131) * * *$ & \\
\hline $\begin{array}{l}\text { Are you an entrepreneur? (No) } \\
\text { Yes }\end{array}$ & $0.4967(0.0324) * * *$ & \\
\hline $\begin{array}{l}\text { Do you want to be an entrepreneur within } 5 \text { years? (No) } \\
\text { Yes }\end{array}$ & $0.9246(0.0115) * * *$ & \\
\hline $\begin{array}{l}\text { Does your family have a business? (None) } \\
\text { Father } \\
\text { Mother } \\
\text { Both }\end{array}$ & $\begin{array}{l}0.0439(0.0136) * * \\
0.0266(0.0240) \\
0.0599(0.0114) * *\end{array}$ & \\
\hline $\begin{array}{l}\text { Do you combine working and studying (No)? } \\
\text { Yes }\end{array}$ & $0.0296(0.0114) * *$ & \\
\hline $\begin{array}{l}\text { Have you done an entrepreneurship course? (None) } \\
\text { Mandatory } \\
\text { Voluntary } \\
\text { Note(s): } * * * p \text {-value }<0.01 ; * * p \text {-value }<0.05 ; * \text {-value }<0.1 \\
\text { Source(s): Compiled by the authors }\end{array}$ & $\begin{aligned}-0.0104(0.0171) \\
0.0667(0.0105)\end{aligned}$ *** & $\begin{array}{r}\text { Table } 3 . \\
\text { Fixed effects of the } \\
\text { multiple linear } \\
\text { regression model }\end{array}$ \\
\hline
\end{tabular}

\begin{tabular}{lrr}
\hline Area of study & Value & \\
\hline Economics & 0.05870 & \\
Engineering & 0.01470 & \\
Health sciences & 0.01569 & \\
Law & -0.00652 & -0.02660 \\
Sciences & -0.03035 & Random effects of the \\
Education and psychology & -0.02561 & multiple linear \\
Arts & & regression model \\
Source(s): Compiled by the authors & & \\
\hline
\end{tabular}

information. The information amassed for the subsample of Spanish university students has enabled us to contribute to the evidence concerning factors that intervene in the entrepreneurial spirit of university students in this country.

For some of the factors, such as age, previous employment experience and family entrepreneurial tradition, the same conclusions can be drawn from the results of this study as have been drawn in many previous studies. For instance, here it was also found that female university students present less entrepreneurial spirit than their male counterparts (Arribas and Vila, 2007; Quevedo et al., 2010; Rubio-López et al., 1999), that family entrepreneurial tradition positively influences entrepreneurial spirit in young university students (Ndofirepi, 2020; Rubio-López et al., 1999) and that combining paid work with studying is a factor related to greater entrepreneurial spirit (Alejandro et al., 2010; León et al., 2006). 


\section{HESWBL}

Figure 2.

Effect of entrepreneurial spirit according to taking entrepreneurship courses on a voluntary or mandatory basis by area of study
However, for other factors such as age, this study presented results that differ from previous studies. In general, an older age was shown to always be a relevant factor in terms of starting the entrepreneurial process given that, with the passage of time, people gain experience and accumulate the knowledge that determines the capacity to identify and exploit business opportunities. Nevertheless, there are factors that diminish the propensity to be an entrepreneur after a certain age threshold (González-Pernía et al., 2019). The 2018-2019 report for Spain detected that two groups presented the least propensity: those aged between 25 and 34 years and those between 55 and 65 years. In the present study, the sample was made up of university students meaning that the age range was very limited, (i.e. focused on the population's youngest age range) which, in turn, has not allowed us to capture the variability in entrepreneurial spirit with respect to the age factor.

Lastly, this study enabled us to shed light on the disparate results obtained in the current literature concerning entrepreneurship education and its effect on the entrepreneurial spirit of young university students. As mentioned previously, some investigations have contributed evidence of the positive effect entrepreneurial education has on entrepreneurial spirit or intentions, while yet others have presented results totally to the contrary. In our opinion, this disparity is caused by the fact that most of the studies carried out to date have not been based on a homogeneous population in relation to the area of study and have not considered whether the study programme is mandatory or voluntary.

This analysis, which is based on a sample comprised students from all areas of study and takes the types of education in entrepreneurship (voluntary or mandatory) into account, has led to three new contributions. First, it can be stated that there are differences in entrepreneurial spirit depending on the area of study. To this effect, students from economics, engineering and health sciences present, per se, a higher entrepreneurial spirit. Second, the effect of mandatory education in entrepreneurship is nil in all areas of study. In other words, mandatory education in entrepreneurship has no effect on entrepreneurial spirit. Third, voluntary entrepreneurial education has a positive effect on the spirit to be an entrepreneur in all areas of study, except economics and law. To this effect, it can be observed that economics students already have entrepreneurial spirit, and so any educational action regarding entrepreneurship has no effect on them. To the contrary, law students have no initial entrepreneurial drive, and so no educational action in the field of entrepreneurship has any effect.

Aware of the fact that one of the objectives of higher education should be to ensure that students develop the capacities and acquire the skills needed to promote creativity, flexibility, the capacity to adapt and the ability to learn to learn, European governments have made teaching entrepreneurship a priority. Drawing on a large number of public resources,

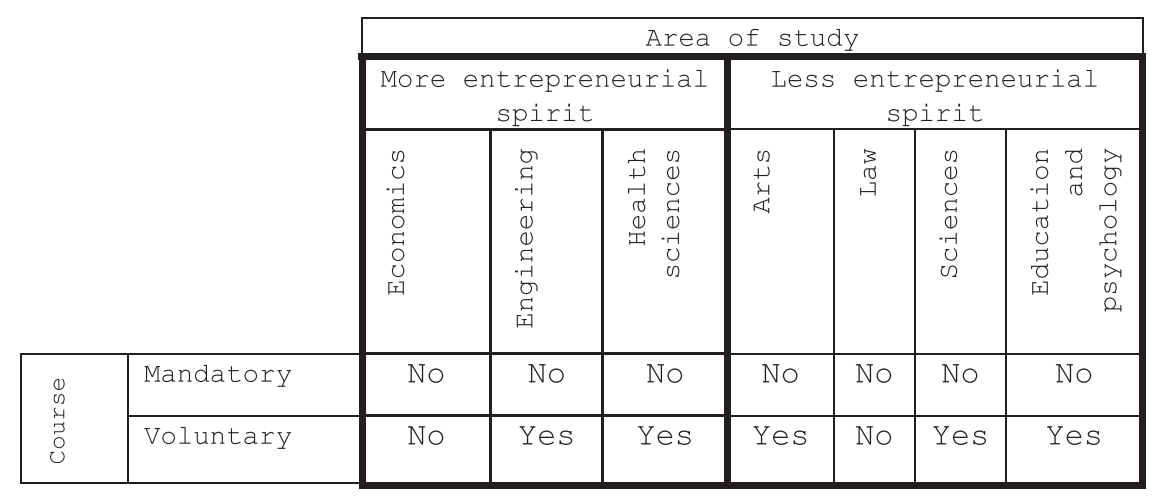


entrepreneurship has become established public policy in universities which, in turn, should change mentalities and shape those with the capacities and skills to start companies, thus generate employment and stimulate the economies in the region. Consequently, education in entrepreneurship is not only regarded as a technique for those that have decided to be entrepreneurs but has also become a political instrument with which to increase the numbers of individuals opting to start their own businesses.

As such, the results obtained in this study are relevant because they will help education programmes in entrepreneurship within universities to be designed more effectively and efficiently and help to assign resources to where they can be made the best use of, i.e. in voluntary entrepreneurship education that cuts across all areas of undergraduate study. Furthermore, from these results, special interventions can be made in the areas that show a lower index of entrepreneurial spirit but will potentially benefit from this education programme.

Addressing the issue of entrepreneurship education in this way involves a decided commitment to changing traditional models based on merely transmitting content considered by others as essential for developing entrepreneurial skills to ones that are based on taking into account the particularities of each person. Furthermore, this change must occur within a framework of personalised education, flexible curricula and the provision of the structural changes required to facilitate these multidisciplinary approaches.

If universities find the courage to be innovative at the level of teaching structures, they will be able to contribute to the rest of society with new initiatives and solutions. Not only must research be understood from the perspective of transferring knowledge to the productive and social sectors but so too should teaching. This is the way forward to actively intervening in the socioeconomic development, the region where their influence must be most felt.

\section{Notes}

1. So as not to overload the article unnecessarily, the results of the linear return models are not shown.

\section{References}

Ahn, T. and Park, J.W. (2017), "The effect of entrepreneurship education on the career path of university students", Asia-Pacific Journal of Business Venturing and Entrepreneurship, Vol. 13 No. 2, pp. 177-192.

Ajzen, I. (1991), "The theory of planned behavior", Organizational Behavior and Human Decision Processes, Vol. 50 No. 2, pp. 179-211.

Alejandro, E., Loli, P., Téllez Dextre Jara, E., Carpio, J. and La Jara, E. (2010), “Actitudes de creatividad y emprendimiento en estudiantes de la Universidad nacional de ingeniería y su relación con algunas variables socio demográficas", Revista de investigación en psicología, Vol. 13 No. 2, pp. 139-151.

Arribas, I. and Vila, J.E. (2007), "Human capital determinants of the survival of entrepreneurial firms in Spain", International Entrepreneurship Management, Vol. 3 No. 3, pp. 309-322.

Bell, J., Wilbanks, J.E. and Dearman, D. (2015), "Business planning course on student entrepreneurial intentions", Journal of Entrepreneurship Education, Vol. 18 No. 1, pp. 169-182.

Díaz-García, C., Sáez-Martínez, F. and Jiménez-Moreno, J. (2015), "Evaluación del impacto del programa educativo 'Emprendedores' en la intención emprendedora de los participantes", Universities and Knowledge Society Journal, Vol. 12 No. 3, pp. 17-31.

Fayolle, A. and Gailly, B. (2013), "The impact of entrepreneurship education of entrepreneurial attitudes and intentions: hysteresis and persistence", Journal of Small Business Management, Vol. 53 No. 1, pp. 75-93. 
García-Rodríguez, F., Gil-Soto, E. and Ruiz-Rosa, I. (2012), "New methods in university entrepreneurship education: a multidisciplinary teams approach", Creative Education, Vol. 3 No. 26, pp. 878-883.

González-Pernía, J.L., Guerrero, M., Montero, J., Peña-Legazkue, I., Ruiz Navarro, J., Camelo Ordaz, C., Diánez, J.P., Estrada Lavilla, R., Bayón, J., Barrabés, C. and Costas, A. (2019), Global Entrepreneurship Monitor (GEM): Informe GEM España 2018-2019, Ed. Universidad de Cantabria, España.

Guerrero, M. and Serey, T. (2018), Global Entrepreneurship Monitor, Reporte Nacional Chile 2018, Universidad del Desarrollo.

Hassan, N.A. (2020), "University business incubators as a tool for accelerating entrepreneurship: theoretical perspective", Reviews of Economics and Political Science, ahead of print, doi: 10.1108/ REPS-10-2019-0142.

Jaen, I., Fernandez-Serrano, J. and Liñan, F. (2013), "Valores culturales, nivel de ingresos y actitud emprendedora", Revista de Economia Mundial, No. 35, pp. 21-45.

Küttim, M., Kallaste, M., Venesaar, U. and Kiss, A. (2014), "Entrepreneurship education at university level and students' entrepreneurial intentions”, Procedia - Social Behavioural Sciences, Vol. 110 No. 24, pp. 658-668.

León, J.A.M., Descals, F.J.P. and Domínguez, J.F.M. (2006), "El perfil psicosocial del emprendedor universitario", Revista de psicología del trabajo y de las organizaciones, Vol. 22 No. 1, pp. 269-284.

Levia, J., Alegre, J. and Monge, R. (2014), "The influence of entrepreneurial learning in new firms' performance: a study in Costa Rica”, Innovar, Vol. 24 No. spe, pp. 129-140.

Liñán, F., Rodríguez-Cohard, J.C. and Rueda-Cantuche, J.M. (2010), "Factors affecting entrepreneurial intention levels: a role for education”, International Entrepreneurship and Management Journal, Vol. 7 No. 2, pp. 195-218.

Liñán, F., Fernández-Serrano, J. and Romero, I. (2013), "Necessity and opportunity entrepreneurship: a cultural effect”, Revista de Economía Mundial, Vol. 33 No. 33, pp. 27-51.

McDonald, S., Gan, B.C., Fraser, S.S., Oke, A. and Anderson, A.R. (2015), "A review of research Methods in entrepreneurship 1985-2013", International Journal of Entrepreneurial Behavior and Research, Vol. 21 No. 3, pp. 291-315.

Merino, M. and Vargas Chanes, D. (2011), "Evaluación comparativa del potential emprendedor de Latinoamérica: una perspectiva multinivel”, Academia. Revista Latinoamericana de Administración No. 46, pp. 38-54.

Mourao, P. and Shneider Locatelli, D.R. (2020), "Testing McClelland at the academy: an analysis of entrepreneurial behavioral characteristics", Sustainability, Vol. 12 No. 5, p. 1771.

Ndofirepi, T.M. (2020), "Relationship between entrepreneurship education and entrepreneurial goal intentions: psychological traits as mediators", Journal of Innovation and Entrepreneurship, Vol. 9 No. 1, doi: 10.1186/s13731-020-0115-x.

Prodan, I. and Drnovsek, M. (2010), "Conceptualizing academic-entrepreneurial intentions: an empirical test”, Academy of Management Annual Meeting Proceeding, Vol. 30 No. 5, pp. 332-347.

Quevedo Monjarás, L.M., Izar Landeta, J.M. and Romo Rojas, L. (2010), "Factores endógenos y exógenos de mujes y hombres emprendedores en España, Estados Unidos y México", Investigación Científica, Vol. 18 No. 46, pp. 57-63.

Quezada, M.E., Vega-Valero, C.Z. and Nava-Quiroz, C. (2020), "Análisis bibiométrico y de contenido a la producción científica de la psicología con relación al estudio del emprendimiento: hacia una nueva propuesta conceptual", Revista de psicología y ciencias del comportamiento, Vol. 11 No. 2, pp. 169-195.

Reynolds, P. (2017), “Tracking the entrepreneurial process with the Panel study of entrepreneurial dynamics (PSED) protocol”, Oxford Research Ecycolopedia of Business Management, Oxford University Press. 
Rubio López, E., Cordón Pozo, E. and Agote Martín, A.L. (1999), "Actitudes hacia la creación de empresas: un modelo explicativo", , Revista Europea de Dirección y Economía de la Empresa, Vol. 8 No. 3, pp. 37-52.

Saji, B.S. and Nair, A.R. (2018), "Effectiveness of innovation and entrepreneurship education in UAE Higher Education", Academy of Strategic Management Journal, Vol. 17 No. 4, pp. 1-12.

Salazar Carvajal, P., Herrera Sánchez, I., Rueda Mendez, S. and León Rubio, J. (2014), "El efecto de la conservación de recursos sobre la intención emprendedora en el contexto de crisis económica: el rol moderador de la autoeficacia y la creatividad”, Anales de Psicología, Vol. 30 No. 2, pp. 549-559.

Salcedo Muñoz, V., Arias Montero, V., Nuñez Guale, L., Robalino Rivadeneira, A., Nugra Betancourth, M. and Salcedo Muñoz, R. (2018), "El emprendimiento de los estudiantes universitarios en Ecuador: caso Universidad Técnica de Machala", INNOVA Research Journal, Vol. 3 No. 7, pp. 84-94.

Sieger, P., Fueglistaller, U. and Zellweger, T. (2011), Entrepreneurial Intentions and Activities of Students Across the World: International Report of GUESSS 2011, KMU-HSG.

Valencia, J., Montoya, I. and Montoya, A. (2015), "Explanatory factors of entrepreneurial intentions among university students", Espacios, Vol. 36 No. 5, pp. 1-15.

\section{Corresponding author}

Laura Vall-1losera Casanovas can be contacted at: laura.vall_llosera@udg.edu

For instructions on how to order reprints of this article, please visit our website:

www.emeraldgrouppublishing.com/licensing/reprints.htm

Or contact us for further details: permissions@emeraldinsight.com 